\title{
Emotionally Intelligent Leadership in Educational Context
}

\author{
Tamara Kuprina \\ Ural Federal University \\ Svetlana Minasyan \\ Moscow State University of Economics, Statistics \\ and Informatics (Yerevan Branch)
}

T

he problems of modern education system are of great interest at present. In general the crux of the matter consists in teaching professionals who are able to work in complex cross-cultural conditions but lack educational programs. As it is, they should promote technological knowledge as well as special skills, supporting communication with numerous representatives of multicultural environment.

One of the most productive methods of teaching is primal (emotionally intelligent) leadership created on the investigations in the field of emotional intelligence which can be the base for developing the emotional cross-cultural competence. So, future specialists can get the main skills in this sphere at universities and develop them, taking into consideration the constantly changeable professional context.

At the same time this method demands primal leadership skills of lecturers who should become leaders themselves and demonstrate emotional skills, appropriate behavior and activity in groups of students especially at the initial stage of education.

The concept of emotionally intelligent leadership is absolutely new as it is based on the idea of emotion management and aims at making response as the main motivating factor in the process of education. Up to now this aspect of teaching process has been treated as insignificant and has been ignored by educationalists. Moreover, emotions have been considered to be intolerable at work. Still, modern investigations come to prove their exceptional importance because any leader motivates his or her followers, influences how the problem is interpreted, proposes variants of solution and even emotional reactions to it.

Despite the fact that at present there are a lot of theories of leadership and factors of its effectiveness, there is no universal definition of it. The Russian scientist O.N. Belokon (2009:60) describes some of them:

1. Leadership is a center of group processes and a leader is a central figure, integrator of these processes and relationships. It should be admitted that it is the earliest definition of the phenomenon.

2. Leadership is a characteristic feature of the personality and his or her influence. It is an art of making people obey which displays the strength of personality, combinations of characteristic features which help to motivate in achieving the purpose.

3. Leadership is a result of group cooperation. This definition is the most actual and reflects the basic meaning of the phenomenon.

4. Leadership is the influence on the choice of aims and organizational strategies, their realization, on saving the group, the followers and their organizational culture.

O.N. Belokon (2009:61) also admits the difference between such terms as "leader- 
ship" and "headship", referring to S.Gibb (1969) who paid attention to the double nature of the term "leadership". According to him, we can speak about leadership only if the leader's influence is accepted by his or her followers on a voluntary basis, or if they share common views. Otherwise it becomes headship.

So, we can determine the term "leadership" only in the context of the present paper.

The emotionally intelligent leadership model is synthesized on the basis of emotional intelligence and leadership investigations by D.Goleman, R.Boyatzis, A.MacKee (2008:10). But they admit that in most countries the effective methods of business management have not evolved yet. We should also note that though the western management system has been developed for many years, this phenomenon is absolutely new in Russia and, accordingly, its evolvement cannot avoid imitation of the western management models.

From our point of view emotionally intelligent leadership based on consciousness of self and others has large perspectives in business as well as in other organizations.

In our article we would like to pay special attention to the double aspect of leadership, adapting it to the educational situation. On the one hand, a leader can be a lecturer of the group which can be considered as a model of any teaching organization. The lecturer can demonstrate necessary skills with the help of an educational system which is organized properly. On the other hand, by learning lessons of leadership, the students acquire professionally oriented skills, i.e. professional competence, one of which is the emotional skill.

M.L. Shankman, S.J. Allen (2008:4) offered a new model of developing emotional intelligence in educational organizations. "It was developed in three ways. First of all, Marcy and Scott summarized the theoretical and practical materials on the topic of leadership development. They worked a lot in the colleges on the subject of leadership. Besides, emotionally intelligent leadership is a combination of many ideas concerning transformational leadership (Bass 1985; Burns 1978), situational leadership (Blanchard 1991), contingency theory (Fiedler 1972), leader - member exchange and emotional intelligence (Bar-On 1997; Goleman 1998; Goleman, Boyatzis, McKee 2002; Salovey, Mayer 1990; Segal 1997; Weisinger 1998), authentic leadership development (Avolio, Luthan 2006), positive psychology, organizational culture and organizational behavior. They interviewed dozens of students in North America."

M.L. Shankman, S.J. Allen (2008:4) point out that personal experience is very important, too. Everybody should have their own style of leadership and followership. But in any case we must develop our skills because effective leadership is based on responsibilities, knowledge and flexible behavior which can be achieved by practice.

The development of students' leadership skills is one of the complex but achievable goals.

As Susan R.Komives (2008: xii ), co-editor of "The Handbook of Student Leadership Program", says, in college you have a great opportunity to study and use your knowledge and leadership skills in practice. M.L. Shankman, S.J. Allen add (4:1) that in college students seem to be in a wonderful laboratory where they can take part in different projects, experiments, life in the campus and also outdoor activities, starting from the life in the city and at home, up to students' clubs and organizations. 
M.L. Shankman, S.J. Allen summarize some experience in this sphere in their book (2008:1), admitting that in spite of the numerous definitions of the term "leadership" (Amazon.com - more than 178 000, Google - 269 million), not so many publications are addressed to teaching students leadership skills. They underline that students' audience is a vast teaching laboratory, a lot of opportunities for training leadership skills for 4-5 years. Students can experiment with their approaches to leadership, mastering the most suitable philosophy and style.

Generally, M.L. Shankman, S.J. Allen (2008:2) come to the conclusion that teaching leadership to students should be done through: 1 . The man or woman people look to in times of need; 2 .The person who can be depended on to provide direction and guidance to others; 3.The person who wants to make a difference in the lives of others; 4.The one who is known for personal insights and strong convictions for the cause in which you believe; 5.The person who is known for an inclusive approach and the ability to work through differences.

The main peculiarity of the method consists in teaching the students to be both leaders and followers. Unfortunately, this approach is often out of the scope of discussions about leadership.

Leadership is the connection between leaders, their followers and context. It means that in any situation leaders introduce certain knowledge, skills and abilities.

Followers are the second part of the leadership and they cannot be underestimated. In reality they determine success and failure of leadership. A leader must be able to motivate his or her followers, otherwise it will be difficult for them to achieve goals.

Context is the third part of leadership dynamics. Context includes the environment where leaders and their followers work (Shankman 2008:12), more exactly, it combines the environment and situation. The environment is the structure of the organization with leader - follower leadership. The situation includes different forces in a definite place and time as well as personalities and organizational policy. It should be mentioned that situations are dynamic. Any new context demands different knowledge and skills both on part of the leaders and followers.

Many people underestimate the role of followers and context. We may suppose if something works well now it will last out in the future. If this does not happen, people blame others and the external factors. It means that we must take into consideration both the internal and external factors for successful communication in a new, changeable environment.

As an example we can imagine lecturers working in different cultural contexts. They have to adapt their scheme of teaching according to the cultural context, since their followers (students), the socio-economic conditions and other variables are culturally different.

Thus, the essence of emotionally intelligent leadership is an ability to adapt to the context and then to motivate followers, taking into account their needs.

Thus, we can speak about specific competences of the lecturer (leader) without which it is impossible to realize even a brilliant project. After all, only a team governed by an emotionally competent leader can be a success. In this situation the lecturers can improve their methods of teaching and motivation, management of audience. 
When leaders provoke positive emotions, they can support the best abilities of their followers, in order to make a kind of response. When they provoke negative reactions, there appears a kind of dissonance which damages the emotional background of the team.

It may take place both on the verbal and non-verbal levels of communication. Students feel the emotional attitude of their lecturers (leaders). Though lecturers may say nothing, students follow their behavior to see the reaction and build their own behavior.

According to investigations, emotional intelligence skills are not inborn, but they may be developed. There is no leader who masters all these different skills equally. Besides, there are a lot of ways and styles to master them.

D.Goleman, R.Boyatzis, A MacKee (2008:266) have determined the following set of emotional intelligence skills:

1. Personal skills - skills including emotional consciousness of self: an adequate self-esteem and analysis of emotions and their influence, realizing one's strong and weak points by using one's own experience. According to the founder of American Leadership Forum J.Jaworski (2008:34) states: "Before you can lead others, before you can help others, you have to discover yourself" (quoted in Shankman 2008:34).

Self-control is another important quality. One must be positive, control his/her negative emotions, be flexible to changes, persistent, full of initiative, active not to lose a chance. Emotionally intelligent leadership includes the positive vision of the situation and future.

2. Social skills - skills determining our consciousness of others, where empathy is a decisive factor for achieving the main goal of the leader, i.e. making response, understanding other people, their position and problems.

Communicative context helps to realize empathy. Listening with empathy does not mean only physical perception because we perceive both words and proxemics. S. Covey (1989) considers empathy as one of the main qualities of highly effective leaders: "seek first to understand, then be understood" (quoted in Shankman 2008:78).

In this context we can discuss the problem of citizenship, i.e. the obligations and responsibilities that a person has as a citizen. But, once again, citizenship depends on cultural context because it has different meanings for different people.

In the context of teaching the students of "World Economics" specialization, the following statements should be mentioned:

"From the point of view of the world economics, empathy is the most important art for adequate interrelation with colleagues and people of other countries. Intercultural dialogue has always been prone to errors and misunderstanding. In this situation empathy is a means which allows people to understand the peculiarities of non-verbal behavior and decode the emotional message behind the words" (Goleman 2008:35).

Having the skills mentioned above, any leader can manage relationships, set goals and motivate his/her followers, symbolizing a corporate culture, confidence and reliability.

Admittedly, communicative leaders have a set of competences. They can listen to others, establish rapport, have good consciousness of the self and others. It is absolutely important for leaders to understand that goals can be achieved cooperatively. 
Besides, the development of relationships on the basis of emotional intelligence with people who differ from us allows us to see our environment differently.

The main idea is to consider differences as valuable properties but not as barriers. Thus as a Chinese proverb says, "nephrite can be extracted from the stone of somebody else's mountain as well."

Leaders having developed emotional intelligence can build a team (student group), set an example of cooperation. The members of a team develop their potential, talents, personal skills which support an organization in general.

A real team should have a high level of confidence which takes time to build. Effective communication is a necessary component of a team.

Moreover, in the epoch of distance working by e-mail, skype or telephone, the question of establishing good relationships is becoming more and more important.

It is also actual for the system of education to implement the system of distance learning, establish virtual cabinets and laboratories of linguodidactics.

Thus, the main competence of the most successful the leaders is competence based on emotional intelligence. The more emotional intelligence skills leaders have, the more effective they can become as they have flexible attitude to different situations (contexts).

As the members of the 2001 international virtual conference have noted, new methods of teaching are determined by a new lifestyle, which demands changes. The role of lecturers has changed essentially, too. At present they cannot just be organizers of the teaching process but should become coaches and advisers who support their students' self-dependent education (see Reference 3).

\section{References:}

1. Belokon, O.V. (2009) Emotsionalny i socialny intellect i fenomen liderstva. // Socialny i emotsionalny intellect: ot protsessov k izmereniyam. Pod red. D.V. Lusina, D.V. Ushakova. M.: Institut psikhologii RAN.

2. Goleman, D.; Boyatzis, R.; McKee, A. (2008) Emotsionalnoe liderstvo (Primal leadership). M.: Alpina Biznes Buks.

3. Informatsionnie $i$ kommunikativnie tekhnologii v rusistike: sovremennoe sostoyanie i perspective. (2010) // III Mezhdunarodnaya virtualnaya nauchno-practicheskaya konferentsiya. Sbornik nauchnikh dokladov. EF MESI. Yerevan: Limush.

4. Kuprina, T.V. (2010) Razvitie emotsionalnogo intellekta. Neobhodimoe uslovie sovremennogo obrazovatelnogo protsessa. // Mezhdunarodniy zhurnal prikladnikh i fundamentalnikh issledovaniy. N12. M.: Akademiya Estestvoznaniya.

5. Kuprina, T.V.; Minasyan, S.M.; Ruda, O.V. (2010) Upravlenie emotsiyami v zerkale crosskulturnih issledovaniy. Yerevan: Limush.

6. Shankman, M.L.; Allen, S.J. (2008) Emotionally Intelligent Leadership. // A Guide for College Students. USA: Jossey-Bass. 


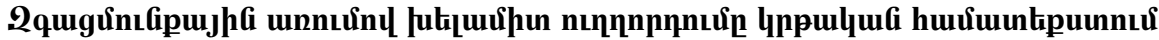

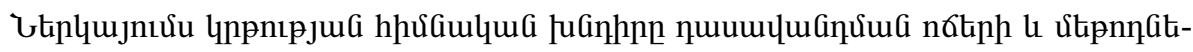

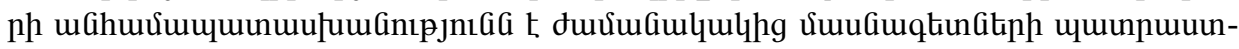

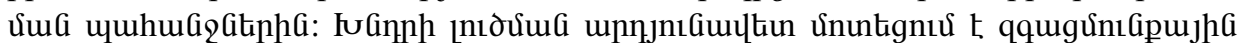

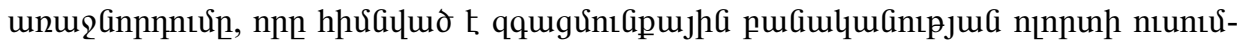

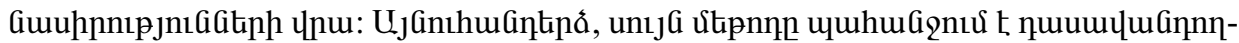

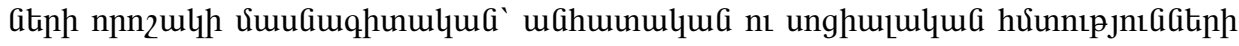
qupqugnıu: 